\title{
Factors associated with bronchopulmonary aspiration: a national-based study
}

\author{
Fatores associados à aspiração broncopulmonar: estudo de base nacional \\ Factores asociados con la aspiración broncopulmonar: estudio de base nacional
}

\begin{tabular}{|c|c|}
\hline \multicolumn{2}{|c|}{$\begin{array}{l}\text { Jaqueline Helena Tanner' } \\
\text { ORCID: 0000-0002-7908-6665 }\end{array}$} \\
\hline \multicolumn{2}{|c|}{$\begin{array}{l}\text { Cristina Mara Zamarioli' } \\
\text { ORCID: 0000-0002-4757-7611 }\end{array}$} \\
\hline \multicolumn{2}{|c|}{$\begin{array}{l}\text { Magda Machado de Miranda Costa" } \\
\text { ORCID: 0000-0002-6598-0113 }\end{array}$} \\
\hline ORCID: 0000-0003-0110-5157 & Heiko Thereza Santana' \\
\hline \multicolumn{2}{|c|}{$\begin{array}{l}\text { Ana Clara Ribeiro Bello dos Santos" } \\
\text { ORCID: 0000-0002-4598-9022 }\end{array}$} \\
\hline \multicolumn{2}{|c|}{ Cleide Felicia de Mesquita Ribeiro" } \\
\hline \multicolumn{2}{|c|}{$\begin{array}{l}\text { Fernanda Raphael Escobar Gimenes' } \\
\text { ORCID: 0000-0002-5174-112X }\end{array}$} \\
\hline \multicolumn{2}{|c|}{$\begin{array}{r}\text { 'Universidade de São Paulo. Ribeirão Preto, São Paulo, Brazil. } \\
\text { "Agência Nacional de Vigilância Sanitária. Brasília, } \\
\text { Distrito Federal, Brazil. }\end{array}$} \\
\hline \multicolumn{2}{|c|}{$\begin{array}{r}\text { How to cite this article } \\
\text { Tanner JH, Zamarioli CM, Costa MMM, Santana HT, } \\
\text { Santos ACRB, Ribeiro CFM, et al. Factors associated with } \\
\text { bronchopulmonary aspiration: a national-based study } \\
\text { Rev Bras Enferm. 2022;75(3):e20210220 } \\
\text { https://doi.org/10.1590/0034-7167-2021-0220 }\end{array}$} \\
\hline \multicolumn{2}{|c|}{$\begin{array}{l}\text { Corresponding author: } \\
\text { Fernanda Raphael Escobar Gimenes } \\
\text { E-mail: fregimenes@eerp.usp.br }\end{array}$} \\
\hline \multicolumn{2}{|c|}{$\begin{array}{l}\text { EDITOR IN CHIEF: Antonio José de Almeida Filhc } \\
\text { ASSOCIATE EDITOR: Ana Fátima Fernande }\end{array}$} \\
\hline Submission: $04-20-2021$ & Approval: 08-20-2021 \\
\hline
\end{tabular}

\begin{abstract}
Objectives: to determine the prevalence of bronchopulmonary aspiration in the Brazilian scenario, the factors associated with the incident and the variables associated with death. Methods: a cross-sectional and analytical study, carried out from analysis of notifications of incidents related to bronchopulmonary aspiration of the Health Surveillance Notification System, from January 2014 to December 2018. Results: of the 264,590 notifications, 553 referred to aspiration, whose prevalence rate was $0.21 \%$. There was an association between the event and age, ethnicity, main medical diagnosis, country region, service type, health unit and consequences for patients. Furthermore, four independent predictor variables for death were found: living in the North or South regions, being elderly and receiving healthcare at night. Conclusions: the prevalence rate of bronchopulmonary aspiration was small, but with a negative impact on patients.
\end{abstract}

Descriptors: Patient Safety; Risk Management; Respiratory Aspiration; Pneumonia, Aspiration; Health Information Systems.

\section{RESUMO}

Objetivos: determinar a prevalência de aspiração broncopulmonar no cenário brasileiro, os fatores associados ao incidente e as variáveis associadas ao óbito. Métodos: estudo transversal e analítico, realizado a partir da análise das notificações de incidentes relacionados à aspiração broncopulmonar do Sistema de Notificações em Vigilância Sanitária, no período de janeiro de 2014 a dezembro de 2018. Resultados: das 264.590 notificações, 553 se referiam à aspiração, cuja taxa de prevalência foi de $0,21 \%$. Houve associação entre o evento e idade, etnia, diagnóstico médico principal, região do país, tipo de serviço, unidade de saúde e consequência para o paciente. Ainda, verificaram-se quatro variáveis preditoras independentes para o óbito: residir na Região Norte ou Sul, ser idoso e receber atendimento à saúde no período noturno. Conclusões: a taxa de prevalência de aspiração broncopulmonar foi pequena, mas com impacto negativo para os pacientes.

Descritores: Segurança do Paciente; Gestão de Riscos; Aspiração Respiratória; Pneumonia Aspirativa; Sistemas de Informação em Saúde.

\section{RESUMEN}

Objetivos: determinar la prevalencia de broncoaspiración en el escenario brasileño, los factores asociados al incidente y las variables asociadas a la muerte. Métodos: estudio transversal y analítico, realizado a partir del análisis de notificaciones de incidentes relacionados con la aspiración broncopulmonar del Sistema de Notificación de Vigilancia Sanitaria, de enero de 2014 a diciembre de 2018. Resultados: de las 264.590 notificaciones, 553 se refirieron a aspiración, cuya tasa de prevalencia fue del $0,21 \%$. Hubo asociación entre el evento y la edad, etnia, diagnóstico médico principal, región del país, tipo de servicio, unidad de salud y consecuencias para el paciente. Además, se encontraron cuatro variables predictoras independientes de muerte: vivir en la región Norte o Sur, ser anciano y recibir atención médica por la noche. Conclusiones: la tasa de prevalencia de aspiración broncopulmonar fue pequeña, pero con impacto negativo en los pacientes.

Descriptores: Seguridad del Paciente; Gestión de Riesgos; Aspiración Respiratoria; Neumonía por Aspiración; Sistemas de Información en Salud. 


\section{INTRODUCTION}

Bronchopulmonary aspiration, defined as the inhalation of oropharyngeal or gastric content or a foreign body into the airway that goes beyond the vocal folds $s^{(1-2)}$, is a serious and potentially fatal event. Its incidence varies from $0.7 / 10,000^{(1)}$ to $10 / 10,000^{(2)}$, reaching $38 \%$ in patients with severe trauma and $4.4 \%$ to $90 \%$ in hospitalized patients with enteral nutrition ${ }^{(1)}$. Furthermore, the event is responsible for $10 \%$ to $30 \%$ of deaths associated with anesthesia ${ }^{(1)}$ and are more common in children ${ }^{(3)}$ and the elderly ${ }^{(4)}$.

The causes of bronchopulmonary aspiration include marked disturbance of consciousness, decreased gastrointestinal motility, impaired oral hygiene, medications, mechanical ventilation therapy, enteral tube and dysphagia due to neurological disease or aging $^{(4)}$, the latter being the most important and an independent predictor of mortality ${ }^{(1)}$.

Clinical indicators of bronchopulmonary aspiration include sudden onset of respiratory symptoms (such as severe coughing and cyanosis) associated with ingestion of food, liquid, or regurgitation of gastric contents and sudden change in voice (such as hoarseness or a gurgling noise) after swallowing. It is noteworthy that smallvolume aspirations, which do not produce overt symptoms, are more common and are generally not discovered until the condition progresses to aspiration pneumonia(5).

Aspiration pneumonia is a serious complication and is considered a leading cause of death in the elderly population ${ }^{(6)}$. The mortality rate depends on the volume and content of the aspirate, reaching $70 \%{ }^{(7)}$. Aspiration pneumonia represents 5 to $15 \%$ of hospital pneumonia ${ }^{(8)}$ and can cost health institutions around US\$ 4,300 per day, per patient, in addition to conferring a triple risk of death within 30 days $^{(9)}$.

In Brazil, from August 2019 to July 2020, 86 deaths were related to bronchopulmonary aspiration and accounted for about $9 \%$ of the total notifications of deaths due to adverse events (AE) reported in the Health Surveillance Notification System (NOTIVISA - Sistema de Notificações em Vigilância Sanitária) of the Brazilian National Health Surveillance Agency (ANVISA - Agência Nacional de Vigilância Sanitária). Therefore, bronchopulmonary aspiration was the second leading cause of death in the country ${ }^{(10)}$, drawing attention to the importance of risk management, especially in the elderly and pediatric populations, which are more vulnerable to the event due to the specificity of the stages of development ${ }^{(10)}$.

Reducing harm associated with healthcare is one of nurses' duties and responsibilities, who need to develop skills and competences in tracking patients at risk for bronchopulmonary aspiration as well as in planning nursing care focused on results.

Furthermore, although studies have been published internationally on risk factors for bronchopulmonary aspiration, most were conducted in a single healthcare institution and included a specific group of patients ${ }^{(6,11-12)}$. Furthermore, the factors associated with death from bronchopulmonary aspiration have not been fully elucidated, especially in the national scenario.

\section{OBJECTIVES}

To determine the prevalence of bronchopulmonary aspiration in the Brazilian scenario, the factors associated with this important safety incident and the variables associated with death.

\section{METHODS}

\section{Ethical aspects}

The study was approved by the Institutional Review Board of the Escola de Enfermagem de Ribeirão Preto at Universidade de São Paulo. As this is secondary data analysis, waiver of the Informed Consent Form was requested.

\section{Study design, period and place}

This is a cross-sectional and analytical study, carried out with secondary data from the NOTIVISA database. STrengthening the Reporting of Observational Studies in Epidemiology (STROBE) was used.

\section{Database}

The database used to identify and analyze cases of bronchopulmonary aspiration in Brazil was NOTIVISA, a computerized system on the web platform, developed by ANVISA to receive notifications of incidents related to healthcare, including $A E$, technical complaints and human poisoning related to the use of products and services under health surveillance ${ }^{(13)}$.

\section{Population, and inclusion and exclusion criteria}

All notifications of incidents related to healthcare reported by the Patient Safety Centers (NSP) in the period from January 1 , 2014 to December 31, 2018 were considered, which followed the implementation of the Brazilian National Patient Safety Program (PNSP - Programa Nacional de Segurança do Paciente) $)^{(14)}$.

The population consisted of 264,590 notifications, which were classified into: (i) patient accidents; (ii) documentation failure; (iii) failure to identify the patient; (iv) failure in the transfusion or graft procedure; (v) failures during healthcare; (vi) failures during the surgical procedure; (vii) failures in diet administration; (viii) failure to administer $\mathrm{O} 2$ or medicinal gases; (ix) failures in radiological assistance; (x) failure in administrative activities; (xi) failures in patient care/protection; (xii) failures occurring in clinical or pathology laboratories; (xiii) patient fall; (xiv) burns; (xv) pressure injury; and (xvi) others ${ }^{(15)}$.

The most frequently reported incidents in NOTIVISA are those of the "others" category, which has an open field for the event description. The main ones include failures involving probes, failures involving venous catheters, accidental endotracheal extubation, patient avoidance, venous thromboembolism (VTE) and bronchoaspiration ${ }^{(15)}$. For this reason, these notifications were read in full for tracking cases involving bronchopulmonary aspiration. It is noteworthy that the NSP used the following terms to report bronchopulmonary aspiration in NOTIVISA: bronchoaspiration, bronchopneumonia, aspiration pneumonia and ventilator-associated pneumonia (VAP).

The other categories that were not specifically related to pulmonary aspiration were excluded from the analysis.

\section{Study protocol}

The database was made available by ANVISA's Surveillance and Monitoring Management in Health Services (GVIMS - Gerência de 
Vigilância e Monitoramento em Serviços de Saúde) in a Microsoft Excel spreadsheet.

For the purposes of the study, bronchopulmonary aspiration was defined as the inhalation of oropharyngeal or gastric content or foreign body into the airway that goes beyond the vocal folds ${ }^{(1-2)}$. Analyzed variables were:

- Country region: North, Northeast, Southeast, Center-West and South.

- Patient characteristics - Sex: female or male; age: $<28$ days, 29 days to 1 year, 2 to 4 years, 5 to 11 years, 12 to 17 years, 18 to 25 years, 26 to 35 years, 36 to 45 years, 46 to 55 years, 56 to 65 years, 66 to 75 years, 76 to 85 years and $>85$ years; ethnicity:yellow, indigenous, brown, black and not informed; main medical diagnosis according to the chapters of the International Classification of Diseases, $10^{\text {th }}$ edition (ICD-10).

- Incident characteristics/adverse event-Period: daytime (7 a.m. to 7 p.m.), nighttime (7 p.m. to 7 a.m.), did not know how to inform; consequence for patients: none, mild, moderate, severe and death ${ }^{(16)}$; service type: hospital, clinic, health center/basic health unit, clinics, pharmacy, blood center or transfusion agency, radiology, clinical/microbiological/pathological anatomy laboratory, nuclear medicine, hemodialysis services, mental health or psychiatric services or institutions, exclusive emergency service (e.g., ECU), others; health unit: outpatient clinic, operating room, day hospital, radiology, clinical/microbiological/pathological anatomy laboratory, nuclear medicine, inpatient sectors, transport services (ambulance); care phase: during consultation, admission, during care (diagnosis, assessment, treatment or surgical intervention), transfer to another unit or to another health service, discharge, post-discharge follow-up, was not hospitalized.

\section{Analysis of results, and statistics}

Analyzes were performed using the R program, version 5.5.3. Initially, a descriptive analysis of study variables was conducted using absolute $(\mathrm{n})$ and relative frequencies (\%). The prevalence rate of bronchopulmonary aspiration was calculated by dividing the total number of healthcare-related incidents reported as bronchopulmonary aspiration by the total number of incidents reported in the period, multiplied by 100 .

To verify the factors associated with bronchopulmonary aspiration, age was stratified into age groups: $<18$ years, adult (from 19 to 65 years) and elderly (>66 years); ethnicity, into whites, blacks and others; main medical diagnosis, into diseases of the circulatory system, diseases of the digestive system, diseases of the respiratory system, diseases of the nervous system, neoplasms (tumors) and others; country region, into North, Northeast, CenterWest, Southeast and South; health service type, into inpatient, outpatient and other. Therefore, to assess associations between outcome (bronchopulmonary aspiration) and explanatory variables (sex, age group, ethnicity, main diagnosis, country region, care period and phase, health unit where the incident occurred), we used the chi-square or Fischer's exact tests.

To identify the factors associated with death from bronchopulmonary aspiration and explanatory variables (sex, age group, ethnicity, main diagnosis, country region, service type, health unit and care period), chi-square or Fischer's exact tests were also used.

The selection of explanatory variables for the final logistic regression model was performed using the Akaike information criterion (AIC). To verify the measure of association, the Odds Ratio (OR) of the variables that, at $5 \%$ significance level, remained in the final logistic regression model was calculated. $95 \%$ Confidence Interval $(\mathrm{Cl})$ was also calculated.

\section{RESULTS}

There was a total of 264,590 notifications of incidents related to healthcare; of these, 553 were related to bronchopulmonary aspiration, whose prevalence rate was $0.21 \%$. Most involved males (312; $56.4 \%)$, aged 76 to 85 years $(147 ; 26.6 \%)$ and white $(166 ; 30 \%)$ (Table 1$)$.

Table 1 - Distribution of bronchopulmonary aspiration cases reported in NOTIVISA according to sex, age and ethnicity ( $n=553)$, Brazil, January 2014 to December 2018

\begin{tabular}{lcc}
\hline Sociodemographic variables & $\mathbf{n}$ & $\%$ \\
\hline Sex & & \\
Female & 241 & 43.6 \\
Male & 312 & 56.4 \\
Age & & \\
<28 days & 16 & 2.9 \\
29 days to 1 year & 16 & 2.9 \\
2 to 4 years & 0 & 0.0 \\
5 to 11 years & 2 & 0.4 \\
12 to 17 years & 2 & 0.4 \\
18 to 25 years & 6 & 1.1 \\
26 to 35 years & 15 & 2.7 \\
36 to 45 years & 30 & 5.4 \\
46 to 55 years & 44 & 8.0 \\
56 to 65 years & 89 & 16.1 \\
66 to 75 years & 96 & 17.4 \\
76 to 85 years & 147 & 26.6 \\
$>$ 85 years & 90 & 16.3 \\
Ethnicity & & \\
White & 166 & 30.0 \\
Yellow & 4 & 0.7 \\
Brown & 85 & 15.4 \\
Indigenous & 2 & 0.4 \\
Black & 6 & 1.1 \\
Not reported & 290 & 52.4 \\
\hline Source: Health Surveillance Notification System (NOTIVISA). & & \\
\hline
\end{tabular}

Among the notifications involving bronchopulmonary aspiration ( $n=553)$, in $136(24.6 \%)$, patients presented diseases of the respiratory system, followed by diseases of the nervous system $(80 ; 14.5 \%)$, diseases of the circulatory system $(64 ; 11.6 \%)$ and neoplasms ( $58 ; 10.5 \%)$. Also, the Southeast region was responsible for most of notifications (229; 41.4\%) (data not presented in tables).

Table 2 shows that the majority of cases of bronchopulmonary aspiration occurred during the daytime period (324;58.6\%), in care provision $(546 ; 98.7 \%)$, in hospitals $(540 ; 97.6 \%)$ and hospitalization units $(347 ; 62.0 \%)$. Moreover, the majority resulted in moderate damage to patients $(225 ; 40.7 \%)$ and death occurred in $7.3 \%$ of the cases $(n=41)$.

There was a significant association between bronchopulmonary aspiration and age group $(p<0.001)$, ethnicity $(0.029)$, main medical diagnosis $(p<0.001)$, country region ( $p<0.001)$, service type $(p<0.001)$, health unit $(p<0.001)$ and consequences for patients $(p<2.2 e-16)$ (Table 3). 
Table 2 - Distribution of bronchopulmonary aspiration cases reported in NOTIVISA according to period and care phase, service type, health unit and consequence for patients ( $n=553)$, Brazil, January 2014 to December 2018

\begin{tabular}{|c|c|c|}
\hline Incident variables & $\mathbf{n}$ & $\%$ \\
\hline \multicolumn{3}{|l|}{ Care period } \\
\hline Daytime (7 a.m. to 7 p.m.) & 326 & 58.3 \\
\hline Nighttime (7 p.m. to 7 a.m.) & 121 & 21.6 \\
\hline Do not know how to inform & 112 & 20.1 \\
\hline \multicolumn{3}{|l|}{ Care phase } \\
\hline Was not hospitalized & 1 & 0.2 \\
\hline On admission & 2 & 0.4 \\
\hline During care provision & 552 & 98.6 \\
\hline In the moments of transfer & 2 & 0.4 \\
\hline In post-discharge follow-up & 2 & 0.4 \\
\hline \multicolumn{3}{|l|}{ Service type } \\
\hline Outpatient & 9 & 1.6 \\
\hline Inpatient & 547 & 97.8 \\
\hline Emergency & 2 & 0.2 \\
\hline Other & 1 & 0.4 \\
\hline \multicolumn{3}{|l|}{ Health unit } \\
\hline Radiology & 1 & 0.2 \\
\hline Hospitalization Units & 350 & 62.7 \\
\hline Intensive Care Units & 164 & 29.3 \\
\hline Operating center & 10 & 1.8 \\
\hline Emergency & 18 & 3.2 \\
\hline Others & 4 & 0.7 \\
\hline$N A^{*}$ & 12 & 2.1 \\
\hline \multicolumn{3}{|l|}{ Consequences for patients } \\
\hline None & 13 & 2.3 \\
\hline Mild & 205 & 36.7 \\
\hline Moderate & 224 & 40.1 \\
\hline Severe & 76 & 13.6 \\
\hline Death & 41 & 7.3 \\
\hline
\end{tabular}

*NA-Not applicable, this option is checked when there is no specific "Unit".

Source: Health Surveillance Notification System (NOTIVISA, version 2.0).

A significant association was also identified between death by bronchopulmonary aspiration and age group $(p=0.008)$, main medical diagnosis $(p=0.043)$, country region $(p=0.002)$ and care period $(p=0.014)(4)$.

Table 5 shows the logistic regression model corresponding to the risk of death from bronchopulmonary aspiration. Four independent predictor variables for death were verified: living in the North $(p=0.0094)$ or South $(p=0.0414)$, being elderly $(p=0.0059)$ and receiving healthcare at night $(p=0.0065)$.

\section{DISCUSSION}

This is the first study carried out at the national level, aiming at analyzing the prevalence of bronchopulmonary aspiration, as well as the factors associated with this important safety incident and with death from the event. Furthermore, it is the first study that includes all age groups in the analyses.

The prevalence of bronchopulmonary aspiration was low when compared to the literature, which ranges from $10 \%$ to $70 \%{ }^{(17)}$. However, more than half of notifications analyzed in this study resulted in moderate or severe damage.

Bronchopulmonary aspiration is a potentially preventable event that, when present, can result in disastrous consequences for patients. The severity depends on the volume and characteristics of the aspirated substance as well as the defense capacity of the patients' body ${ }^{(18)}$. Although large volume aspirations occasionally occur, clinically silent aspirations are the most common.

According to the American Society of Critical Care Nurses ${ }^{(19)}$, more than $40 \%$ of adult patients with acute illness have bronchopulmonary aspiration. Previous research carried out in American Intensive Care Units (ICUs) also revealed that microaspirations occurred in almost half of critically ill patients, mechanically ventilated and with an enteral tube ${ }^{(8)}$. Furthermore, the risk of pneumonia was four times higher in these people, when compared to less severe patients and with a lower level of care complexity. The researchers concluded that bronchopulmonary aspiration results in greater use of hospital resources and that modifiable risk factors need to be monitored.

Nurses must carry out the clinical assessment of patients, which will guide the survey of accurate and accurate nursing diagnoses, as well as the judgment of priorities, the elaboration of desired results and the selection of appropriate interventions for patients at risk.

In this study, the number of cases of bronchopulmonary aspiration in children younger than 28 days was also small. The result differs from a previous study, which demonstrated that the event is slightly more common in this population than in adults. Also, children seem to be less severely affected ${ }^{(3)}$.

It should be taken into account that newborns have difficulties in coordinating the sucking and swallowing reflexes and may manifest physiological gastroesophageal reflux. Additionally, due to the stage of oral development, children up to 18 months of age tend to take objects to their mouths, increasing the risk of aspiration of foreign bodies and airway obstruction ${ }^{(20)}$.

Table 3 - Analysis of the association between bronchopulmonary aspiration and sex, age group, main medical diagnosis, country region, care period and phase $(\mathrm{N}=264,590)$, Brazil, January 2014 to December 2018

\begin{tabular}{|c|c|c|c|c|c|c|c|}
\hline \multirow{3}{*}{ Explanatory variables } & \multicolumn{6}{|c|}{ Bronchopulmonary aspiration } & \multirow{3}{*}{$p$ value $^{\dagger}$} \\
\hline & \multicolumn{2}{|c|}{ No } & \multicolumn{2}{|c|}{ Yes } & \multicolumn{2}{|c|}{ Total* } & \\
\hline & $\mathbf{n}$ & $\%$ & $\mathbf{n}$ & $\%$ & $\mathbf{n}$ & $\%$ & \\
\hline \multicolumn{8}{|l|}{ Sex } \\
\hline Female & 125.436 & 47.5 & 241 & 43.6 & 125.677 & 47.5 & \multirow{2}{*}{0.065} \\
\hline Male & 138.593 & 52.5 & 312 & 43.6 & 138.906 & 52.5 & \\
\hline \multicolumn{8}{|l|}{ Age group } \\
\hline$<18$ years & 33.976 & 12.9 & 36 & 6.5 & 34.013 & 12.9 & \multirow{3}{*}{$<0.001$} \\
\hline Adults & 128.306 & 48.6 & 184 & 33.3 & 128.490 & 48.6 & \\
\hline Elderly & 101.747 & 38.5 & 333 & 60.2 & 102.080 & 38.6 & \\
\hline \multicolumn{8}{|l|}{ Ethnicity } \\
\hline White & 78.275 & 29.6 & 166 & 30.0 & 78.441 & 29.6 & \multirow{4}{*}{0.029} \\
\hline Indigenous & 305 & 0.1 & 2 & 0.4 & 307 & 0.1 & \\
\hline Black & 7.505 & 2.8 & 6 & 1.1 & 7.511 & 2.8 & \\
\hline Other & 177.950 & 67.4 & 379 & 68.5 & 178.330 & 67.4 & \\
\hline
\end{tabular}




\begin{tabular}{|c|c|c|c|c|c|c|c|}
\hline \multirow{3}{*}{ Explanatory variables } & \multicolumn{6}{|c|}{ Bronchopulmonary aspiration } & \multirow{3}{*}{$\boldsymbol{p}$ value $^{\dagger}$} \\
\hline & \multicolumn{2}{|c|}{ No } & \multicolumn{2}{|c|}{ Yes } & \multicolumn{2}{|c|}{ Total* } & \\
\hline & $\mathbf{n}$ & $\%$ & $\mathbf{n}$ & $\%$ & $\mathbf{n}$ & $\%$ & \\
\hline \multicolumn{8}{|l|}{ Main medical diagnosis } \\
\hline Diseases of the circulatory system & 35.212 & 13.3 & 64 & 11.6 & 35.276 & 13.3 & \multirow{6}{*}{$<0.001$} \\
\hline Diseases of the digestive system & 20.634 & 7.8 & 63 & 11.4 & 20.697 & 7.8 & \\
\hline Diseases of the respiratory system & 39.809 & 15.1 & 136 & 24.6 & 39.945 & 15.1 & \\
\hline Diseases of the nervous system & 25.778 & 9.8 & 80 & 14.5 & 25.858 & 9.8 & \\
\hline Neoplasms (tumors) & 19.697 & 7.5 & 58 & 10.5 & 19.755 & 7.5 & \\
\hline Other & 122.899 & 46.5 & 152 & 27.5 & 123.052 & 46.5 & \\
\hline \multicolumn{8}{|l|}{ Country region } \\
\hline Center-West & 32.898 & 12.5 & 106 & 19.2 & 33.004 & 12.5 & \multirow{5}{*}{$<0.001$} \\
\hline Northeast & 46.142 & 17.5 & 96 & 17.4 & 46.238 & 17.5 & \\
\hline North & 11.125 & 4.2 & 19 & 3.4 & 11.144 & 4.2 & \\
\hline Southeast & 121.685 & 46.1 & 229 & 41.4 & 121.915 & 46.1 & \\
\hline South & 52.185 & 19.8 & 103 & 18.6 & 52.288 & 19.8 & \\
\hline \multicolumn{8}{|l|}{ Service type } \\
\hline Inpatient & 247.581 & 93.8 & 540 & 97.6 & 248.122 & 93.8 & \multirow{3}{*}{$<0.001$} \\
\hline Outpatient & 2.595 & 1.0 & 10 & 1.8 & 2.605 & 1.0 & \\
\hline Other & 13.852 & 5.2 & 3 & 0.5 & 13.855 & 5.2 & \\
\hline \multicolumn{8}{|l|}{ Health unit } \\
\hline Outpatient & 2.194 & 0.8 & 0 & 0.0 & 2.194 & 0.8 & \multirow{6}{*}{$<0.001$} \\
\hline Inpatient sectors & 129.742 & 49.1 & 343 & 62.0 & 130.085 & 49.2 & \\
\hline Intensive Care Unit & 71.725 & 27.2 & 167 & 30.2 & 71.892 & 27.2 & \\
\hline Emergency & 18.503 & 7.0 & 17 & 3.1 & 18.520 & 7.0 & \\
\hline Other & 21.125 & 8.0 & 13 & 2.4 & 21.139 & 8.0 & \\
\hline $\mathrm{NA}^{\ddagger}$ & 20.746 & 7.9 & 13 & 2.4 & 20.759 & 7.8 & \\
\hline \multicolumn{8}{|l|}{ Care period } \\
\hline Daytime (7 a.m. to 7 p.m.) & 156.930 & 59.4 & 324 & 58.6 & 157.254 & 59.4 & \multirow{3}{*}{0.910} \\
\hline Nighttime/early morning (7 a.m. to 7 p.m.) & 55.981 & 21.2 & 117 & 21.2 & 56.098 & 21.2 & \\
\hline Did not know how to inform & 51.117 & 19.4 & 112 & 20.3 & 51.230 & 19.4 & \\
\hline \multicolumn{8}{|l|}{ Consequences for patients } \\
\hline None & 83.843 & 31.7 & 14 & 0.01 & 83.857 & 31.7 & \multirow{5}{*}{$<2.2 \mathrm{e}-16^{\mathrm{s}}$} \\
\hline Mild & 138.740 & 52.4 & 197 & 0.07 & 138.937 & 52.5 & \\
\hline Moderate & 33.342 & 12.6 & 225 & 0.09 & 33.567 & 12.7 & \\
\hline Severe & 6.647 & 2.5 & 76 & 0.03 & 6.723 & 2.5 & \\
\hline Death & 1.455 & 0.5 & 41 & 0.02 & 1.496 & 0.6 & \\
\hline
\end{tabular}

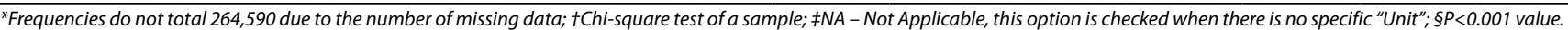
Source: Health Surveillance Notification System (NOTIVISA, version 2.0)

Table 4 - Analysis of the association between death by bronchopulmonary aspiration and sex, age group, main medical diagnosis and care period ( $\mathrm{n}=553$ ), Brazil, January 2014 to December 2018

\begin{tabular}{|c|c|c|c|c|c|c|c|}
\hline \multirow{3}{*}{ Explanatory variables } & \multicolumn{6}{|c|}{ Death by bronchopulmonary aspiration } & \multirow{3}{*}{$p$ value } \\
\hline & \multicolumn{2}{|c|}{ Yes } & \multicolumn{2}{|c|}{ No } & \multicolumn{2}{|c|}{ Total* } & \\
\hline & $\mathbf{n}$ & $\%$ & $\mathbf{n}$ & $\%$ & $\mathbf{n}$ & $\%$ & \\
\hline \multicolumn{8}{|l|}{ Sex } \\
\hline Female & 16 & 39.0 & 224 & 43.2 & 240 & $42.9 \%$ & \multirow{2}{*}{$0.541^{\dagger}$} \\
\hline Male & 25 & 61.0 & 294 & 56.8 & 319 & $57.1 \%$ & \\
\hline \multicolumn{8}{|l|}{ Age group } \\
\hline Adult & 6 & 14.6 & 178 & 34.8 & 184 & 33.3 & \multirow{3}{*}{$0.008^{+}$} \\
\hline Elderly & 34 & 82.9 & 299 & 58.4 & 333 & 60.2 & \\
\hline Less than 18 & 1 & 2.4 & 35 & 6.8 & 36 & 6.5 & \\
\hline \multicolumn{8}{|l|}{ Ethnicity } \\
\hline White & 14 & 34.1 & 152 & 29.7 & 166 & 30.0 & \multirow{4}{*}{$0.210^{\ddagger}$} \\
\hline Indigenous & 1 & 2.4 & 1 & 0.2 & 2 & 0.4 & \\
\hline Black & 0 & 0.0 & 6 & 1.2 & 6 & 1.1 & \\
\hline Other & & & & & & & \\
\hline \multicolumn{8}{|l|}{ Main medical diagnosis } \\
\hline II - Neoplasms & 0 & 0.0 & 58 & 11.3 & 58 & $10.5 \%$ & \multirow{6}{*}{$0.043^{\ddagger}$} \\
\hline VI - Diseases of the nervous system & 7 & 17.1 & 73 & 14.3 & 80 & $14.5 \%$ & \\
\hline IX - Diseases of the circulatory system & 4 & 9.8 & 60 & 11.7 & 64 & 11.6 & \\
\hline $\mathrm{X}$ - Diseases of the respiratory system & 7 & 17.1 & 129 & 25.2 & 136 & 24.6 & \\
\hline $\mathrm{XI}$ - Diseases of the digestive system & 8 & 19.5 & 55 & 10.7 & 63 & 11.4 & \\
\hline Others & 15 & 36.6 & 137 & 26.8 & 152 & 27.5 & \\
\hline \multicolumn{8}{|l|}{ Country region } \\
\hline Center-West & 10 & 24.4 & 96 & 18.8 & 106 & 19.2 & \multirow{5}{*}{$0.002^{+}$} \\
\hline Northeast & 8 & 19.5 & 88 & 17.2 & 96 & 17.4 & \\
\hline North & 5 & 12.2 & 14 & 12.2 & 19 & 3.4 & \\
\hline Southeast & 17 & 41.5 & 212 & 41.4 & 229 & 41.4 & \\
\hline South & 1 & 2.4 & 102 & 19.9 & 103 & 18.6 & \\
\hline
\end{tabular}




\begin{tabular}{|c|c|c|c|c|c|c|c|}
\hline \multirow{3}{*}{ Explanatory variables } & \multicolumn{6}{|c|}{ Death by bronchopulmonary aspiration } & \multirow{3}{*}{$p$ value } \\
\hline & \multicolumn{2}{|c|}{ Yes } & \multicolumn{2}{|c|}{ No } & \multicolumn{2}{|c|}{ Total* } & \\
\hline & $\mathbf{n}$ & $\%$ & $\mathbf{n}$ & $\%$ & $\mathbf{n}$ & $\%$ & \\
\hline \multicolumn{8}{|l|}{ Service type } \\
\hline Inpatient & 40 & 97.6 & 500 & 97.7 & 540 & 97.6 & \\
\hline Outpatient & 0 & 0.0 & 10 & 2.0 & 10 & 1.8 & $0.232^{\ddagger}$ \\
\hline Other & 1 & 2.4 & 2 & 0.4 & 3 & 0.5 & \\
\hline \multicolumn{8}{|l|}{ Health unit } \\
\hline Inpatient sectors & 25 & 61.0 & 318 & 62.1 & 343 & 62.0 & \\
\hline Intensive Care Unit & 12 & 29.3 & 155 & 30.3 & 167 & 30.2 & \\
\hline Emergency & 1 & 2.4 & 16 & 3.1 & 17 & 3.1 & $0.699^{\ddagger}$ \\
\hline Other & 2 & 4.9 & 11 & 2.1 & 13 & 2.4 & \\
\hline $\mathrm{NA}^{\ddagger}$ & 1 & 2.4 & 12 & 2.3 & 13 & 2.4 & \\
\hline \multicolumn{8}{|l|}{ Care period } \\
\hline Daytime (7 a.m. to 7 p.m.) & 18 & 43.9 & 306 & 59.8 & 324 & 58.9 & \\
\hline Nighttime (7 p.m. to 7 a.m.) & 16 & 39.0 & 101 & 19.7 & 117 & 21.2 & $0.014^{\dagger}$ \\
\hline Did not know how to inform & 7 & 17.1 & 105 & 20.5 & 112 & 20.2 & \\
\hline
\end{tabular}

*Frequencies do not total 264,590 due to the number of missing data; +Chi-square test of a sample; $\neq$ Fisher's exact test.

Source: Health Surveillance Notification System (NOTIVISA).

Table 5 - Logistic regression model of variables associated with death by bronchopulmonary aspiration, Brazil, January 2014 to December 2018

\begin{tabular}{|c|c|c|c|c|c|c|c|}
\hline Variables & Estimate & $\mathbf{S D}^{*}$ & $z$ value & $\operatorname{Pr}(>|z|)$ & $\mathbf{R C}^{+}$ & $95 \% \mathrm{Cl}^{\ddagger}$ & $\operatorname{Pr}(>|z|)$ \\
\hline Intercept & -3.8026 & 0.5026 & 7.5665 & 0.0000 & & & \\
\hline \multicolumn{8}{|l|}{ Country region } \\
\hline Center-West & 0.3529 & 0.4297 & 0.8214 & 0.4114 & 1.4232 & $0.6131-3.3037$ & 0.4114 \\
\hline Northeast & 0.3574 & 0.4631 & 0.7718 & 0.4403 & 1.4296 & $0.5768-3.5435$ & 0.4403 \\
\hline North & 1.5711 & 0.6050 & 2.5967 & 0.0094 & 4.8119 & $1.4700-15.7512$ & 0.0094 \\
\hline South & -2.1222 & 1.0404 & 2.0397 & 0.0414 & 0.1198 & $0.0156-0.9204$ & 0.0414 \\
\hline \multicolumn{8}{|l|}{ Age group } \\
\hline Elderly & 1.2689 & 0.4609 & 2.7534 & 0.0059 & 3.5570 & $1.4415-8.7775$ & 0.0059 \\
\hline Less than 18 years & -0.4526 & 1.1163 & 0.4054 & 0.6852 & 0.6360 & $0.0713-5.6707$ & 0.6852 \\
\hline \multicolumn{8}{|l|}{$\begin{array}{l}\text { Care period } \\
\quad \text { Davtime ( } 7 \text { a m to } 7 \mathrm{pm} \text { ) }\end{array}$} \\
\hline Nighttime (7 p.m. to 7 a.m.) & 1.0261 & 0.3772 & 2.7202 & 0.0065 & 2.7902 & $1.3321-5.8443$ & 0.0065 \\
\hline Did not know how to inform & 0.1550 & 0.4725 & 0.3280 & 0.7429 & 1.1676 & $0.4625-2.9477$ & 0.7429 \\
\hline
\end{tabular}

*SD - Standard Deviation; OR - Odds Ratio; $95 \% \mathrm{Cl}$ - 95\% Confidence Interval.

Recognizing and managing the risk of aspiration early, especially in children with dysphagia and cerebral palsy, is important to prevent aspiration pneumonia ${ }^{(21)}$ and other serious pulmonary complications $^{(22)}$. In this context, nurses have a preponderant role in managing the risk of bronchopulmonary aspiration in the pediatric population, because one of their attributions is the education and guidance of other nursing team member and parents of vulnerable children. Therefore, health education and constant training of professionals are important strategies that reduce the occurrence of event and improve health outcomes ${ }^{(23)}$.

In this study, bronchopulmonary aspiration affected more people aged between 76 and 85 years. Although this event can occur in all age groups ${ }^{(18)}$, research has shown that aspiration is more frequent in the elderly, especially in those with dysphagia $^{(18,24-26)}$. Researchers also stated that exposure to risk factors, such as age and impaired oral hygiene, can contribute to morbidity and mortality from bronchopulmonary aspiration ${ }^{(18)}$, and these factors should be recognized, evaluated and monitored by health teams, especially in the most susceptible patients.

The elderly population is more prone to bronchopulmonary aspiration, because the aging process results in morphophysiological changes in muscle cells and structures involved in the swallowing process, increasing the amount of residue that accumulates in the mouth after swallowing, episodes of coughing or choking during meals ${ }^{(26-27)}$. In addition to this, one should consider the progressive increase in the incidence of dementia syndromes with advancing age, especially among people aged between 70 and 80 years ${ }^{(26)}$, which contributes to increased event incidence in this population as well as the number of cases of aspiration pneumonia.

Clinical indicators of bronchopulmonary aspiration include the sudden onset of respiratory symptoms, such as severe coughing and cyanosis, associated with ingestion of food, liquid, or regurgitation of gastric contents, and sudden change in voice, including hoarseness or a gurgling noise after swallowing. It is noteworthy that small-volume aspirations, which do not produce overt symptoms, are common and generally not discovered until the condition progresses to aspiration pneumonia ${ }^{(5)}$.

In this context, nurses must recognize their role in the management of risks and injuries related to bronchopulmonary aspiration, including the screening of patients with dysphagia through validated tools, such as the Eating Assessment Tool (EAT$10)^{(28)}$. Although this assessment does not replace that of other multidisciplinary team members, it highlights the importance of screening performed by nurses in improving quality of care provided to vulnerable patients and in identifying early interventions, which should be guided by evidence-based practice and centered on individuals. 
In the present study, most notifications come from the Southeast Region. However, patients living in northern Brazil were four times more likely to have bronchopulmonary aspiration when compared to patients from other regions. Such results can be explained by the different socioeconomic conditions in the country.

The last AE report published by ANVISA also revealed that most notifications of incidents related to healthcare came from the Southeast ${ }^{(29)}$.

Note that notifications in NOTIVISA are made electronically by NSP duly registered with the Agency ${ }^{(13,15)}$. Although notification of bronchopulmonary aspiration and deaths resulting from this $\mathrm{AE}$ are mandatory in the country ${ }^{(15,30)}$, possible difficulties faced in the registration of NSP may impact the number of notifications per Federation Unit as well as the lack of a safety culture in health services.

Robust data is important for tackling inequalities, prioritizing policies and allocating resources to prevent $A E$ and save lives ${ }^{(31)}$. It is recommended that future research be carried out in order to compare the distribution of resources in different states and regions, the Healthcare Network structuring in different territories, the quality and safety of healthcare and the impact of these variables in the number of incident notifications related to bronchopulmonary aspiration.

The study results also showed that, in $7 \%$ of notifications involving bronchopulmonary aspiration, patients died. Also, advanced age was a variable related to the outcome. The results corroborate those of previous research ${ }^{(6,25)}$, which showed that neurological dysfunction, decreased consciousness, gastroesophageal reflux, tube feeding and advanced age are potential risk factors for the occurrence of death ${ }^{(32)}$.

Regarding the other variables associated with death from aspiration identified in this study, the presence of diseases of the respiratory system stands out. According to the Unified Health System Hospital Information System (SIH/SUS), respiratory diseases were the second leading cause of hospitalization in $\mathrm{Brazil}^{(33)}$. In a survey conducted in a Brazilian ICU, $62.5 \%$ of patients with chronic obstructive pulmonary disease required invasive mechanical ventilation. The results also showed a high mortality rate in these patients ${ }^{(34)}$.

Mechanically ventilated patients are unable to clear oropharyngeal secretions; therefore, they are at increased risk for bronchopulmonary aspiration and respiratory infections ${ }^{(18)}$.VAP is one of the consequences of bronchopulmonary aspiration and results in high in-hospital mortality rates ${ }^{(35-36)}$. The VAP prevention bundle, which includes (i) elevated position at 30 and $45^{\circ}$, (ii) daily interruption of sedation and daily assessment of extubation conditions, (iv) peptic ulcer prophylaxis (stress ulcer) and (v) deep vein thrombosis prophylaxis (unless contraindicated) (37), being an important strategy that, when used efficiently, positively impacts patient outcomes and quality of care ${ }^{(25)}$, because it allows nurses and other healthcare professionals to provide the best possible care, supported by evidence-based research and practices ${ }^{(32)}$.
In this study, the risk of death from aspiration was higher at night. Although, in Brazil, most incidents related to healthcare occurred during the day, according to the ANVISA incident notification bulletin ${ }^{(29,38)}$, previous research found that procedures performed at night were responsible for a greater number of pulmonary complications ${ }^{(18,39)}$. This result can be explained by the difference in nursing team size in daytime and nighttime periods. However, research is needed to elucidate the impact of this relationship on patient outcomes ${ }^{(39)}$ and $\mathrm{AE}$ rates.

\section{Study limitations}

The study was carried out based on a retrospective analysis of incident notifications reported by NSPs; for this reason, underreporting of severe and fatal $A E$ may have occurred. The degree of damage is recorded in NOTIVISA by the notifier; therefore, it was not possible to validate this information. Also, NOTIVISA does not allow the inclusion of information related to causes of incidents, a fact that limits analysis of events. The lack of material and infrastructure resources, such as computers and internet access, may have contributed to the lower number of notifications by certain health institutions and country regions.

\section{Contributions to nursing}

The results of this study can contribute to identifying specific care aimed at patients at risk for bronchopulmonary aspiration, in order to minimize the damage caused by the incident and improve quality of care. Knowledge about aspiration risk factors has the potential to support the development of prevention protocols in health units and services and, consequently, reduce the negative impact of the event on health outcomes. They also point to the need for services to invest in a culture of safety and institute policies that favor notifying incidents, with and without damage, in order to improve the understanding of the causes and the identification of appropriate interventions that are sensitive to the results.

\section{CONCLUSIONS}

The prevalence rate of bronchopulmonary aspiration in this study was small, but with a negative impact on patients. There was a significant association between event and age, ethnicity, main medical diagnosis, country region, service type, health unit and degree of damage. Still, the risk factors for death were being elderly, living in the North and South regions and receiving care during the night shift.

It is concluded that bronchopulmonary aspiration is a relevant event, whose risk factors must be identified early and managed by the health team, especially by nurses, in order to reduce the incidence of unfavorable clinical outcomes.

\section{REFERENCES}

1. Macht M, Parfitt A, Wahidi MM. Aspiração aguda [Internet]. London: BMJ Best Practice; 2018[cited 2021 Mar 17]. Available from: https:// bestpractice.bmj.com/topics/pt-br/528/pdf/528/Aspira\%C3\%A7\%C3\%A30\%20aguda.pdf

2. Beck-Schimmer B, Bonvini JM. Bronchoaspiration: incidence, consequences and management. Eur J Anaesthesiol. 2011;28(2):78-84. https:// doi.org/10.1097/EJA.0b013e32834205a8 
3. Flick RP, Schears GJ, Warner MA. Aspiration in pediatric anesthesia: is there a higher incidence compared with adults?. Curr Opin Anaesthesiol. 2002;15(3):323-7. https://doi.org/10.1097/00001503-200206000-00008

4. Cichero JAY. Age-related changes to eating and swallowing impact frailty: aspiration, choking risk, modified food texture and autonomy of choice. Geriatrics (Basel). 2018;3(4):69. https://doi.org/10.3390/geriatrics3040069

5. Palmer JL, Metheny NA. Preventing aspiration in older adults with dysphagia. Am J Nurs. 2008;108(2):40-8;quiz-9. https://doi. org/10.1097/01.NAJ.0000308961.99857.33

6. Manabe T, Teramoto S, Tamiya N, Okochi J, Hizawa N. Risk factors for aspiration pneumonia in older adults. PLoS One. 2015;10(10):e0140060. https://doi.org/10.1371/journal.pone.0140060

7. Sanivarapu RR, Gibson J. Aspiration pneumonia [Internet]. Treasure Island (FL): StatPearls Publishing; 2021 [cited 2021 Jul 14]. Available from: https://www.ncbi.nlm.nih.gov/books/NBK470459/

8. Metheny NA, Clouse RE, Chang YH, Stewart BJ, Oliver DA, Kollef MH. Tracheobronchial aspiration of gastric contents in critically ill tube-fed patients: frequency, outcomes, and risk factors. Crit Care Med. 2006;34(4):1007-15. https://doi.org/10.1097/01.CCM.0000206106.65220.59

9. Katzan IL, Cebul RD, Husak SH, Dawson NV, Baker DW. The effect of pneumonia on mortality among patients hospitalized for acute stroke. Neuroroly. 2003;60(4):620-5. https://doi.org/10.1212/01.wnl.0000046586.38284.60

10. Agência Nacional de Vigilância Sanitária (BR). Nota técnica no 10/2020. Práticas seguras para a prevenção de aspiração broncopulmonar em serviços de saúde [Internet]. Brasília, DF: ANVISA; 2020[cited 2020 Mar 18]. Available from: https://www.gov.br/anvisa/pt-br/ centraisdeconteudo/publicacoes/servicosdesaude/notas-tecnicas/nota-tecnica-broncoaspiracao-10-12-20.pdf/view

11. Kim JW, Choi H, Jung J, Kim HJ. Risk factors for aspiration pneumonia in patients with dysphagia undergoing videofluoroscopic swallowing studies: A retrospective cohort study. Medicine (Baltimore). 2020;99(46):e23177. https://doi.org/10.1097/MD.0000000000023177

12. Watanabe $S$, Shimozato $K$, Oh-Shige $H$, Umemura M, Fujiwara $S$, Abe $Y$, et al. Examination of factors associated with aspiration pneumonia following stroke. Oral Sci Int. 2014;11(1):15-21. https://doi.org/10.1016/S1348-8643(13)00009-8

13. Agência Nacional de Vigilância Sanitária (BR). Sistema de notificação em vigilância sanitária: Notivisa [Internet]. Brasília, DF: ANVISA; 2018[cited 2020 May 09]. Available from: https://www.gov.br/anvisa/pt-br

14. Ministério da Saúde (BR). Portaria n 529, de 1 de abril de 2013. Institui o Programa Nacional de Segurança do Paciente (PNSP) [Internet]. Brasília, DF: MS; 2013[cited 2021 Mar 17]. Available from: https://bvsms.saude.gov.br/bvs/saudelegis/gm/2013/prt0529_01_04_2013.html

15. Agência Nacional de Vigilância Sanitária (BR). Nota técnica no 05/2019. Orientações gerais para a notificação de eventos adversos relacionados à assistência à saúde [Internet]. Brasília, DF: Gerência de Vigilância e Monitoramento em Serviços de Saúde, Gerência Geral de Tecnologia em ANVISA; 2019 [cited 2020 Mar 10]. Available from: https://www.gov.br/anvisa/pt-br/centraisdeconteudo/publicacoes/ servicosdesaude/notas-tecnicas/nota-tecnica-n-05-2019-gvims-ggtes-anvisa.pdf/view

16. World Health Organization. Conceptual framework for the international classification for patient safety [Internet]. Geneva: World Health Organization; 2009[cited 2011 Dec 6]. Available from: https://apps.who.int/iris/bitstream/handle/10665/70882/WHO_IER_PSP_2010.2_eng. pdf;jsessionid=E75074D1C5371DBF66BD58AD2E7030A2?sequence $=1$

17. DeLegge MH. Aspiration pneumonia: incidence, mortality, and at-risk populations. JPEN J Parenter Enteral Nutr. 2002;26(6 suppl):S19-24; discussion S-5. https://doi.org/10.1177/014860710202600604

18. Kollmeier BR, Keenaghan M. Aspiration risk [Internet]. Treasure Island (FL): StatPearls Publishing; 2021 [cited 2021 Jul 14]. Available from: https://www.ncbi.nlm.nih.gov/books/NBK470169/

19. American Association of Critical-Care Nurses. Practice alert: prevention of aspiration in adults. Alijo Viejo (CA): AACCN; 2018 [cited 2021 Mar 21]. Available from: https://www.aacn.org/clinical-resources/practice-alerts/prevention-of-aspiration

20. Neves OMD, Brasil LMBF, Amorim CSC. Processos aspirativos pulmonares em criança. Rev Paranaense Med [Internet]. 2009[cited 2021 Mar 8];23(3):1-6. Available from: http://files.bvs.br/upload/S/0101-5907/2009/v23n3/a1968.pdf

21. Tanaka N, Nohara K, Ueda A, Katayama T, Ushio M, Fujii N, et al. Effect of aspiration on the lungs in children: a comparison using chest computed tomography findings. BMC Pediatrics. 2019;19(1):162. https://doi.org/10.1186/s12887-019-1531-6

22. Yoon S-I, Kang J-M. Aspiration pneumonia in a pediatric patient under general anesthesia despite adequate preoperative fasting. Korean J Crit Care Med. 2015;30(4):313-7. https://doi.org/10.4266/kjccm.2015.30.4.313

23. McKinney OW, Heaton PA, Gamble J, Paul SP. Recognition and management of foreign body ingestion and aspiration. Nurs Stand. 2017;31(23):42-52. https://doi.org/10.7748/ns.2017.e10449.

24. Mandell LA, Niederman MS. Aspiration pneumonia. N Engl J Med. 2019;380(7):651-63. https://doi.org/10.1056/NEJMra1714562

25. Santos DAR, Arcanjo DPS, Silva GMBM, Mendes ALF, Mendonça SCB, Lima TRCM, et al. Factors associated with aspiration pneumonia and preventive measures in hospitalized elderly: a systematic review of observational studies. Revista CEFAC. 2020;22(6):e2920. https://doi. org/10.1590/1982-0216/20202262920

26. Ebihara S, Sekiya H, Miyagi M, Ebihara T, Okazaki T. Dysphagia, dystussia, and aspiration pneumonia in elderly people. J Thorac Dis. 2016;8(3):632-9. https://doi.org/10.21037/jtd.2016.02.60

27. Di Pede C, Mantovani ME, Del Felice A, Masiero S. Dysphagia in the elderly: focus on rehabilitation strategies. Aging Clin Exp Res. 2016;28(4):607-17. https://doi.org/10.1007/s40520-015-0481-6 
28. Kaspar K, Ekberg O. Identifying vulnerable patients: role of the EAT-10 and the multidisciplinary team for early intervention and comprehensive dysphagia care. Nestle Nutr Inst Workshop Ser. 2012;72:19-31. https://doi.org/10.1159/000339977

29. Agência Nacional de Vigilância Sanitária (BR). Incidentes relacionados à assistência à saúde. Bol Seguranca Paciente Qual Serv Saude [Internet]. 2019 Nov[cited 2021 Mar 9];(20):1-7. Available from: https://www.gov.br/anvisa/pt-br/centraisdeconteudo/publicacoes/ servicosdesaude/boletim-seguranca-do-paciente/boletim-seguranca-do-paciente-e-qualidade-em-servicos-de-saude-n-20-incidentesrelacionados-a-assistencia-a-saude-2018.pdf/view

30. Ministério da Saúde (BR). Resolução RDC № 36, de 25 de julho de 2013. Institui ações para a segurança do paciente em serviços de saúde e dá outras providências [Internet]. Brasília, DF: MS; 2013[cited 2021 Mar 18]. Available from: http://bvsms.saude.gov.br/bvs/saudelegis/ anvisa/2013/rdc0036_25_07_2013.html

31. McCarron K. Understanding care bundles. Nurs Made Incredibly Easy. 2011;9(2):30-3. https://doi.org/10.1097/01.NME.0000394024.85792.42

32. Ministério da Saúde (BR). Morbidade hospitalar do SUS por local de internação [Internet]. Brasília, DF: MS; 2019 [cited 2019 Nov 03]. Available from: http://tabnet.datasus.gov.br/cgi/tabcgi.exe?sih/cnv/niuf.def

33. Pincelli MP, Grumann ACB, Fernandes C, Cavalheiro AGC, Haussen DAP, Maia IS. Characteristics of COPD patients admitted to the ICU of a referral hospital for respiratory diseases in Brazil. J Bras Pneumol. 2011;37(2):217-22. https://doi.org/10.1590/s1806-37132011000200012

34. Kock KS, Rosa BC, Martignago NN, Maurici R. Pneumonia associada à ventilação mecânica (PAVM): incidência e desfecho clínico em uma unidade de terapia intensiva no sul de Santa Catarina. Arq Catarinenses Med [Internet]. 2017[cited 2021 Mar 17];46(1):2-11. Available from: http://www.acm.org.br/acm/seer/index.php/arquivos/article/view/248

35. Sadigov A, Mamedova I, Mammmadov K. Ventilator-associated pneumonia and in-hospital mortality: which risk factors may predict inhospital mortality in such patients?. J Lung Health Dis. 2019;3(4):8-12. https://doi.org/10.29245/2689-999X/2019/4.1157

36. Jadot $L$, Huyghens $L$, De Jaeger A, Bourgeois M, Biarent D, Higuet A, et al. Impact of a VAP bundle in Belgian intensive care units. Ann Intensive Care. 2018;8(1):65. https://doi.org/10.1186/s13613-018-0412-8

37. Agência Nacional de Vigilância Sanitária (BR). Incidentes relacionados à assistência à saúde: 2016. Bol Seguranca Paciente Qual Serv Saude [Internet]. 2017 Dec 28[cited 2021 Mar 16];(15):1-20. Available from: https://www.gov.br/anvisa/pt-br/centraisdeconteudo/publicacoes/ servicosdesaude/boletim-seguranca-do-paciente/boletim-seguranca-do-paciente-e-qualidade-em-servicos-de-saude-no-15.pdf

38. Cortegiani A, Gregoretti C, Neto AS, Hemmes SNT, Ball L, Canet J, et al. Association between night-time surgery and occurrence of intraoperative adverse events and postoperative pulmonary complications. Br J Anaesth. 2019;122(3):361-9. https://doi.org/10.1016/j. bja.2018.10.063

39. Cordova PB, Phibbs CS, Schmitt SK, Stone PW. Night and day in the VA: associations between night shift staffing, nurse workforce characteristics, and length of stay. Res Nurs Health. 2014;37(2):90-7. https://doi.org/10.1002/nur.21582 